\title{
Formulasi Pertanggungjawaban Pidana Korporasi Dengan Adanya Peraturan Mahkamah Agung No. 13 Tahun 2016
}

\author{
Michelle Kristina \\ Fakultas Hukum, Universitas Surabaya, michellekristina@staff.ubaya.ac.id
}

\begin{abstract}
The development of the concept of corporation not only had a positive impact but also followed by the development of crimes that could be done using corporations or also called corporate crime. Many laws and regulations that have accommodated corporation as legal subjects that can be asked for corporate criminal responsibility have not been followed by regulations governing procedures or procedures for examining corporations as perpetrators of criminal acts. This is very necessary because of the differences in characteristics between corporate crime and other conventional crimes. Responding to legal requirements that have been very urgent and there are distinct challenges for law enforcers because of the different treatment, then the Supreme Court issues Supreme Court Rules No. 13 of 2016. The problem regarding the procedure for corporate sentencing involved in criminal offenses is not only talking about material law but also about formal law or its procedural law. One of the aims and objectives of its formation is to fill the vacuum of criminal procedural law which until now has not regulated the procedures for handling corporations that carry out criminal cases. Supreme Court Rules No. 13 of 2016 is a legal rule aimed at assisting law enforcement officials in handling criminal cases with corporate actors and/or their administrators. This then became one form of thinking that could be the basis for assisting in the formation of criminal procedural laws governing corporations.
\end{abstract}

Keywords: Corporation, Corporate Conviction, Corporate Responsibility

\section{Pendahuluan}

\subsection{Latar Belakang}

Perkembangan kehidupan manusia saat ini tidak dapat dilepaskan dari berbagai aspek seperti ekonomi, politik, kebudayaan, teknologi, dan proses globalisasi yang semakin nyata terutama yang dialami oleh bangsa Indonesia dalam era reformasi seperti sekarang ini. Semua aspek tersebut memiliki hubungan serta keterkaitan satu sama lain. Perkembangan tersebut kemudian menyebabkan semakin beragamnya kebutuhan hidup manusia yang harus dipenuhi.

\section{Jurnal}

YUSTIKA

Media Hukum dan Keadilan Fakultas Hukum Universitas Surabaya Vol. XX No. X, Desember 201X P-ISSN: $x x x x x$,
Salah satu cara yang dapat dilakukan untuk memenuhi kebutuhan manusia tersebut adalah dengan membuat korporasi.

Keberadaan korporasi telah banyak memberikan kontribusi dalam memenuhi kebutuhan hidup manusia, contohnya saja dalam bidang ekonomi dengan menciptakan lapangan kerja maupun dari segi pemasukan bagi negara berupa pajak, namun disisi yang lain, perkembangan konsep mengenai korporasi ini juga diikuti dengan semakin berkembangnya kejahatan yang dapat dilakukan dengan menggunakan korporasi atau disebut pula sebagai kejahatan korporasi. 
Hal tersebut tidak dapat dilepaskan dari sifat dasar yang dimiliki oleh korporasi yaitu selalu mencari keuntungan.

Jurnal Yustika

Korporasi dalam proses mencari keuntungan tersebut dapat melakukan segala cara agar keuntungan yang korporasi dapatkan semakin besar atau disebut sebagai anomie of success yaitu sukses tanpa aturan (Edi Yunara, 2005). Contohnya korporasi yang melakukan pembuangan limbah di sembarang tempat dan merusak lingkungan, korporasi yang mempekerjakan buruh dengan gaji yang tidak sesuai, dan korporasi melakukan penggelapan pajak.

Kata "korporasi" itu sendiri merupakan sebuah istilah yang biasa digunakan untuk menyebut badan hukum (rechtpersoon). Korporasi merupakan istilah yang sering dijumpai dalam kehidupan sehari-hari. Secara harfiah korporasi (corporatie, Belanda), corporation (Inggris), corporation (Jerman), berasal dari kata 'corporatio' dalam bahasa Latin. Rudi Prasetyo sebagaimana dikutip oleh Mahrus Ali, menyatakan : "Korporasi merupakan sebutan yang lazim digunakan di kalangan ahli hukum pidana untuk menyebut apa yang biasa dalam hukum lain khususnya dalam bidang hukum perdata, sebagai badan hukum atau dalam bahasa Belanda disebut rechts persoon, dan dalam bahasa Inggris disebut legal entities atau corporation" (Mahrus Ali, 2008). Pendapat tersebut menunjukan bahwa sebutan korporasi secara umum digunakan oleh ahli hukum pidana untuk menyebut apa yang biasanya digunakan oleh ahli hukum dibidang hukum perdata sebagai badan hukum, sehingga kata korporasi dalam hukum pidana dan badan hukum dalam hukum perdata pada dasarnya adalah sama.

Pengertian tentang "korporasi" itu sendiri merupakan hasil dari konsep pemahaman tentang subyek dalam bidang hukum. Subyek hukum adalah manusia atau segala sesuatu oleh hukum diakui sebagai pemilik hak dan kewajiban yang dapat dimintakan pertanggungjawaban. Pemahaman tersebut mengakibatkan subyek hukum dapat dibagi menjadi dua yaitu natuurlijkpersoon atau manusia dan rechtspersoon atau badan hukum. Munculnya konsep pemahaman ini sendiri tidak terlepas dari perkembangan kebutuhan hidup manusia yang semakin beragam dalam jaman modern seperti sekarang ini (Setiyono, 2005).

Perkembangan konsep mengenai pelaku kejahatan yang pada awal mulanya hanya ditujukan kepada manusia semata namun sekarang telah berkembang dapat dilakukan oleh korporasi sehingga menyebabkan hukum pidana dituntut untuk berkembang pula. Hal tersebut dapat dilihat dalam hukum pidana yang dianut oleh Indonesia. Pada awalnya hukum pidana Indonesia melalui Kitab Undang-Undang Hukum Pidana (selanjutnya disingkat dengan KUHP) hanya mengakui manusia sebagai subyek hukum pidana atau KUHP tidak mengenal Korporasi sebagai subyek hukum pidana (asas Universitas Delinquere Non Potest yaitu badan hukum tidak dapat melakukan tindak pidana) (Mahrus Ali, 2008). Hal tersebut disebabkan bahwa konsep awal hukum pidana adalah untuk melindungi individu-individu dari tindakan kejahatan atau pelanggaran yang dilakukan oleh individu-individu yang lain namun hal tersebut telah berkembang sesuai dengan perkembangan jaman pula yaitu ditandai dengan diakuinya badan hukum atau korporasi sebagai subyek hukum pidana dalam peraturan perundang-undangan lebih khusus. Contohnya Undang-Undang Republik Indonesia Nomor 31 tahun 1999 tentang Pemberantasan Tindak Pidana Korupsi jo. Undang-Undang Republik Indonesia Nomor 20 tahun 2001 tentang Perubahan atas Undang-Undang Republik Indonesia Nomor 31 tahun 1999 tentang Pemberantasan Tindak Pidana Korupsi (selanjutnya disebut dengan UU Tindak Pidana Korupsi); Undang-Undang Republik Indonesia Nomor 40 tahun 2007 tentang Perseroan Terbatas (selanjutnya disebut UU Perseroan Terbatas); Undang-Undang Republik Indonesia Nomor 8 tahun 2010 tentang Pencegahan dan Pemberantasan Tindak Pidana Pencucian Uang.
Vol. 21 No. 2, Des 2018

Halaman $\mid 2$

Formulasi

Pertanggung-

jawaban Pidana

Korporasi Dengan

Adanya Peraturan

Mahkamah Agung

No. 13 Tahun 2016

Michelle Kristina 
Jurnal Yustika

Vol. 21 No. 2, Des 2018

Halaman I 3

Formulasi

Pertanggungjawaban Pidana

Korporasi Dengan

Adanya Peraturan

Mahkamah Agung

No. 13 Tahun 2016

Michelle Kristina

Banyaknya peraturan perundang-undangan yang sudah mengakomodasi korporasi sebagai subyek hukum yang dapat dimintai pertanggungjawaban pidana belum diikuti dengan peraturan yang mengatur mengenai prosedur atau tata cara pemeriksaan korporasi sebagai pelaku tindak pidana. Hal ini sangat diperlukan karena adanya perbedaan karakteristik antara kejahatan korporasi dengan kejahatan konvensional lainnya. Sebagaimana pendapat Mahrus Ali yang menyatakan:

Salah satu yang membedakan antara kejahatan korporasi dengan kejahatan konvensional/tradisional pada umumnya, terletak pada karakteristik yang melekat pada kejahatan korporasi itu sendiri, antara lain:

1. Kejahatan tersebut sulit dilihat (low visibility), karena biasanya tertutup oleh kegiatan pekerjaan yang normal dan rutin, melibatkan keahlian profesional dan sistem organisasi yang kompleks;

2. Kejahatan tersebut sangat kompleks (complexity) karena selalu berkaitan dengan kebohongan, penipuan dan pencurian serta sering kali berkaitan dengan sebuah yang ilmiah, teknologi, finansial, legal, terorganisasikan, dan melibatkan banyak orang serta berjalan bertahun-tahun;

3. Terjadinya penyebaran tanggung jawab (diffusion of responsibility) yang semakin luas akibat kompleksitas organisasi;

4. Penyebaran korban yang sangat luas (diffusion of victimization) seperti polusi dan penipuan;

5. Hambatan dalam pendeteksian dan penuntutan (detection and prosecution) sebagai akibat profesionalisme yang tidak seimbang antara aparat penegak hukum dengan pelaku kejahatan;

6. Peraturan yang tidak jelas (ambiguitas law) yang sering menimbulkan kerugian dalam penegakan hukum; dan

7. Sikap mendua status pelaku tindak pidana. Harus diakui bahwa pelaku kejahatan korporasi pada umumnya tidak melanggar peraturan perundang-undangan, tetapi apa yang dilakukan memang merupakan perbuatan yang ilegal (Mahrus Ali, 2013).

Menanggapi kebutuhan hukum yang sudah sangat mendesak serta adanya tantangan tersendiri bagi penegak hukum karena adanya perlakuan yang berbeda antara tata cara penanganan terhadap korporasi dengan tata cara penanganan terhadap subyek hukum orang pada umumnya, maka Mahkamah Agung dalam hal ini memberikan pandangan perlu adanya sebuah aturan yang secara rinci mampu menjawab persoalan ini, terutama dalam ruang lingkup pengadilan yang menjadi pintu dalam menegakkan keadilan.

Keluarnya Peraturan Mahkamah Agung Republik Indonesia Nomor 13 Tahun 2016 Tentang Tata Cara Penanganan Perkara Tindak Pidana Oleh Korporasi (selanjutnya disebut PerMA No. 13 tahun 2016) seolah telah menjadi jawaban atas permasalahan yang ada. Namun, masih adanya kekurangan dalam PerMA No. 13 tahun 2016 ini menyebabkan korporasi yang melakukan tindak pidana dapat lolos dari jerat hukum karena adanya celah hukum yang masih belum mampu dijangkau oleh peraturan perundang-undangan yang ada.

Permasalahan mengenai korporasi sebagai subyek hukum yang dapat menjadi pelaku kejahatan (corporate crime) maupun digunakan sebagai tempat menyembunyikan harta kekayaan hasil tindak pidana guna tidak tersentuh oleh hukum menjadi perhatian yang serius. Namun pemberantasan tindak pidana yang dilakukan oleh korporasi sampai saat ini masih berpusat pada orang per orang, sedangkan subyek hukum berupa badan hukum atau korporasi itu sendiri 
masih sedikit yang dapat disentuh oleh aparat penegak hukum. Hal tersebut disebabkan pula oleh cara-cara prosedur penanganannya yang tidaklah sama dengan tata cara terhadap subyek hukum orang. Ada beberapa perbedaan mendasar sehingga memerlukan pemahaman dan penelitian lebih mendalam mengenai tata cara atau prosedur pemidanaan korporasi yang melakukan tindak pidana.

\subsection{Rumusan Masalah}

Berdasarkan pemaparan latar belakang tersebut, terdapat permasalahan mengenai tata cara prosedur untuk dapat memidanakan korporasi yang melakukan tindak pidana. Oleh sebab itu, rumusan masalah yang dapat ditarik adalah: Apakah peraturan perundang-undangan di Indonesia mengatur secara tepat tata cara untuk dapat memidanakan korporasi yang melakukan Tindak Pidana?

\section{Metode Penelitian}

Tata cara pemidanaan korporasi yang melakukan suatu kejahatan merupakan permasalahan yang sampai saat ini masih menjadi kendala bagi aparat penegak hukum untuk dapat menjerat korporasi baik sebagai pelaku maupun para pengurusnya. Penelitian ini diharapkan mampu memberikan manfaat secara konkret dan mampu mengembangkan ilmu pengetahuan, dan pembangunan hukum nasional. Oleh sebab itu, penelitian ini mampu memberikan pemahaman mengenai peraturan perundang-undangan di Indonesia yang terkait dengan tata cara penanganan korporasi yang melakukan tindak pidana. Penelitian ini akan menggunakan metode pengumpulan data dengan melakukan penelusuran pustaka dengan cara inventarisasi peraturan perundang-undangan yang digunakan untuk membentuk konstruksi hukum yang tepat dalam menganalisis ketentuan hukum tentang pemidanaan korporasi.

\section{Hasil Penelitian dan Pembahasan}

Permasalahan mengenai tata cara pemidanaan korporasi yang terlibat tindak pidana tidak hanya berbicara mengenai hukum materiilnya saja melainkan juga tentang hukum formil atau hukum acaranya. Permasalahan tersebut telah direspons oleh Mahkamah Agung Republik Indonesia dengan mengeluarkan PerMA No. 13 tahun 2016. Berdasarkan konsiderans menimbang huruf c PerMA No. 13 tahun 2016, menyatakan bahwa banyak Undang-Undang di Indonesia yang telah menempatkan Korporasi sebagai subyek tindak pidana yang dapat dimintai pertanggungjawaban namun perkara dengan subyek hukum korporasi yang diajukan dalam proses pidana masih sangat terbatas, salah satu penyebabnya adalah prosedur atau tata cara pemeriksaan korporasi sebagai pelaku masih belum jelas.

Adanya PerMA No. 13 tahun 2016 tersebut, semakin menunjukkan bahwa tidaklah mudah untuk dapat memidanakan korporasi yang melakukan tindak pidana sebagaimana ditentukan oleh undang-undang. Lebih lanjut, pada pasal 2 huruf b PerMA No. 13 tahun 2016, menyatakan bahwa maksud dan tujuan dari adanya PerMA No. 13 tahun 2016 ini adalah untuk mengisi kekosongan hukum khususnya hukum acara pidana dalam penanganan perkara pidana dengan pelaku korporasi dan/atau pengurus korporasi. 
Jurnal Yustika

Vol. 21 No. 2, Des 2018

Halaman I 5

Formulasi

Pertanggungjawaban Pidana Korporasi Dengan Adanya Peraturan Mahkamah Agung No. 13 Tahun 2016 Michelle Kristina

Salah satu maksud dan tujuan dibentuknya PerMA No. 13 tahun 2016 tersebut adalah guna mengisi kekosongan hukum acara pidana yang sampai saat ini belum mengatur mengenai tata cara penanganan korporasi yang melakukan perkara pidana. Hal tersebut tidaklah aneh mengingat saat ini hukum acara pidana masih berpedoman pada Kitab Undang-Undang Hukum Acara Pidana (selanjutnya disebut KUHAP) yang belum mengakui korporasi sebagai subyek hukum.

Salah satu contoh konkret adanya kesulitan dalam penanganan perkara pidana yang melibatkan korporasi sebagai pelaku tindak pidana dibuktikan dengan adanya putusan pengadilan Nomor: 94/Pid.Sus-TPK/2017/PN.Jkt.Pst dan Nomor: 3/Pid.SusTPK/2018/PT.DKI, yang melibatkan PT. DGI sebagai pelaku kejahatan korporasi (crimes for corporation) dalam pusaran Tindak Pidana Korupsi. Berdasarkan putusan tersebut, telah dinyatakan bahwa pengurus PT. DGI, yaitu Direktur Utama PT. DGI melakukan serangkaian tindakan secara melawan hukum agar PT. DGI mendapatkan proyek pemerintah sehingga terjadilah kerugian negara sebagaimana unsur-unsurnya telah terpenuhi dalam pasal 2 ayat (1) dan pasal 18 UU Tindak Pidana Korupsi.

Berdasarkan putusan tersebut, pengadilan dalam hal ini masih berpedoman pada tata cara penanganan perkara pidana dengan menggunakan ketentuan dalam hukum acara pidana, sehingga subyek hukum yang dimintakan pertanggungjawaban masih bersifat orang per orang (pengurus PT. DGI), dan bukan korporasi itu sendiri. Hal ini mengakibatkan konsekuensi hukum dalam amar putusannya yang menempatkan subyek hukum orang sebagai terdakwa yang dijatuhi dengan pidana pokok dan korporasi hanya dijatuhkan pidana tambahan.

Sebagai salah satu bentuk produk hukum yang berlaku dan diakui kedudukannya di dalam hukum, PerMA No. 13 tahun 2016 merupakan aturan hukum yang ditujukan untuk membantu aparat penegak hukum dalam penanganan perkara pidana dengan pelaku korporasi dan/atau pengurusnya. Hal ini kemudian menjadi salah satu bentuk pemikiran yang dapat menjadi cikal bakal dalam membantu pembentukan undang-undang hukum acara pidana yang dapat mengakomodasi kepentingan hukum berkembangnya subyek hukum korporasi dewasa ini.

Akan tetapi, PerMA No. 13 tahun 2016 tersebut dirasa masih belum cukup untuk menjawab permasalahan fundamental mengenai sulitnya pertanggungjawaban pidana korporasi yang melakukan tindak pidana. PerMA No. 13 tahun 2016 dalam pasal 1 memunculkan suatu istilah untuk mendefinisikan luasnya ruang lingkup berkembangnya korporasi. Pasal 1 angka 2 dan 3 PerMA No. 13 tahun 2016 menyatakan adanya Korporasi Induk (parent company) dan Perusahaan Subsidiari (subsidiary company). Hal ini perlu menjadi suatu kajian adanya hubungan hukum yang saling berkaitan antar korporasi, baik itu sebagai Korporasi Induk maupun hubungan hukum antar sesama Perusahaan Subsidiari dengan Korporasi Induk, maupun hubungan hukum lainnya.

Lebih lanjut, pasal 1 angka 2 PerMA No. 13 tahun 2016 menyatakan bahwa: “Korporasi Induk (parent company) adalah perusahaan berbadan hukum yang memiliki dua atau lebih anak perusahaan yang disebut perusahaan subsidiari yang juga memiliki status badan hukum tersendiri." Dengan demikian, ada syarat suatu korporasi dapat dikategorikan sebagai Korporasi Induk, yaitu adanya dua atau lebih anak perusahaan yang memiliki status badan hukum sendiri. Menggunakan pemikiran dengan melihat pada syarat tersebut, maka korporasi yang hanya memiliki satu anak perusahaan tidak dapat dianggap sebagai Korporasi Induk menurut PerMa No. 13 tahun 2016 tersebut. 
PerMA No. 13 tahun 2016 berusaha mengatur secara rinci tata cara atau prosedur penanganan korporasi sebagai pelaku tindak pidana. PerMa No. 13 tahun 2016 melihat dalam meminta pertanggungjawaban pidana korporasi tidak hanya terbatas pada hubungan hukum saja antar korporasi yang saling berkaitan melainkan juga hubungan hukum berupa hubungan kerja atau hubungan lain yang berkaitan dengan tindak pidana yang dilakukan oleh korporasi. Berkaitan dengan pemidanaan terhadap korporasi, berdasarkan pasal 4 ayat (2) PerMA No. 13 tahun 2016 penjatuhan pidana terhadap korporasi dapat dinilai dari adanya 3 kategori kesalahan, yaitu:

1.Korporasi memperoleh keuntungan atau manfaat dari tindak pidana tersebut atau tindak pidana tersebut dilakukan untuk kepentingan korporasi;

2.Korporasi membiarkan terjadinya tindak pidana tersebut;

3.Korporasi tidak melakukan langkah-langkah pencegahan.

Jurnal Yustika Vol. 21 No. 2, Des 2018

Halaman I 6

Formulasi

Pertanggungjawaban Pidana

Korporasi Dengan

Adanya Peraturan Mahkamah Agung

No. 13 Tahun 2016 Michelle Kristina

Ketiga katagori kesalahan tersebut berkaitan dengan adanya teori pertanggungjawaban pidana korporasi. Terdapat beberapa teori pertanggungjawaban pidana yaitu a.) Teori Vicarious Liability; b.) Teori Identifikasi atau The Alter Ego Theory; dan c.) Teori Delegasi. Menurut Sutan Remy Sjahdeini, menyatakan: "Ada dua ajaran pokok yang menjadi landasan bagi pembenaran dibebankannya pertanggungjawaban pidana kepada korporasi. Ajaran-ajaran tersebut adalah doctrine of strict liability dan doctrine of vicarious liability" (Sutan Remy Sjahdeni, 2007). Kedua doktrin tersebut menekankan pada pertanggungjawaban pidana yang dapat dibebakan kepada korporasi karena adanya keterkaitan hubungan antara pegawai/karyawan/orang dalam korporasi dengan korporasi. Namun, terdapat suatu pembatasan pertanggungjawaban pidana korporasi yang dikenal dengan ajaran atau doctrine of ultra vires. Menurut Sutan Remy Sjahdeini, menyatakan: "Ajaran ultra vires atau doctrine of ultra vires merupakan doktrin yang semula berasal dari hukum publik yang kemudian diserap ke dalam hukum tentang badan hukum, terutama hukum tentang perseroan terbatas" (Sutan Remy Sjahdeni, 2007).

Lebih lanjut Sutan Remy Sjahdeini menyatakan: Menurut doktrin tersebut, apabila suatu kontrak dibuat oleh perseroan tidak dalam rangka maksud dan tujuan dari perseroan (beyond the objects of the company), maka kontrak itu disebut ultra vires the company, dan kontrak itu void (tidak sah atau batal demi hukum). Apabila mereka melakukan kegiatan yang demikian dan sebagai akibatnya perseroan mengalami kerugian, maka perseroan dapat meminta agar anggota direksi yang bersangkutan mengganti kerugian itu karena mereka telah melalaikan kewajibannya (Sutan Remy Sjahdeni, 2007). Berdasarkan pendapat tersebut maka keberadaan doktrin ultra vires tersebut ditujukan untuk melindungi atau membatasi sampai sejauh mana korporasi dapat dimintakan pertanggungjawaban pidana korporasi terhadap setiap kegiatan yang dilakukan oleh para pengurus atau anggota korporasinya. Pembatasan tersebut dilakukan karena korporasi tidak bertanggung jawab apabila kegiatan yang dilakukan tidak sesuai atau menyimpang dengan tujuan dari korporasi tersebut.

Sejalan dengan pasal 4 PerMA No. 13 tahun 2016, korporasi dapat dimintakan pertanggungjawaban karena adanya tiga kategori kesalahan korporasi, yaitu korporasi memperoleh keuntungan atau manfaat dari tindak pidana tersebut, korporasi membiarkan terjadinya tindak pidana tersebut, atau korporasi tidak melakukan langkah-langkah pencegahan. Dengan demikian, pasal 4 PerMA No. 13 tahun 2016 tersebut sama sekali tidak bertentangan dengan doktrin ajaran asas ultra vires. Alasan yang mendasarinya bahwa asas ultra vires membatasi pertanggungjawaban korporasi sampai sejauh ruang lingkup tujuan korporasi. Dengan demikian, apabila korporasi mendapatkan keuntungan atau manfaat dari tindak pidana 
Jurnal Yustika

Vol. 21 No. 2, Des 2018

Halaman I 7

Formulasi

Pertanggungjawaban Pidana Korporasi Dengan Adanya Peraturan Mahkamah Agung No. 13 Tahun 2016 Michelle Kristina tersebut maka tindak pidana tersebut dilakukan dalam ruang lingkup tujuan korporasi. Begitu juga dengan alasan korporasi membiarkan terjadinya tindak pidana tersebut dan/atau tidak melakukan langkah-langkah pencegahan, maka korporasi juga dianggap sebagai pelaku tindak pidana dan dapat dimintakan pertanggungjawaban pidana korporasi.

Beberapa hal lainnya di dalam PerMA No. 13 tahun 2016 masih memiliki beberapa hal yang perlu untuk dianalisis secara yuridis. Hal tersebut dapat dilihat dari ketentuan hukum pasal 8 PerMA No. 13 tahun 2016, yang menyatakan bahwa:

(1)Korporasi yang telah bubar setelah terjadinya tindak pidana tidak dapat dipidana, akan tetapi terhadap aset milik Korporasi yang diduga digunakan untuk melakukan kejahatan dan/atau merupakan hasil kejahatan, maka penegakkan hukumnya dilaksanakan sesuai dengan mekanisme sebagaimana diatur dalam peraturan perundang-undangan.

(2)Gugatan terhadap aset yang dimaksud ayat (1) dapat diajukan terhadap mantan pengurus, ahli waris atau pihak ketiga yang menguasai aset milik Korporasi yang telah bubar tersebut.

Berdasarkan ketentuan pasal 8 PerMA No. 13 tahun 2016 tersebut, menimbulkan adanya celah hukum bagi pengurus korporasi yang ingin lepas dari pertanggungjawaban pidana dapat melakukan perbuatan hukum berupa pembubaran korporasi. Hal tersebut dapat terjadi karena PerMA No. 13 tahun 2016 ini lebih mengutamakan pengembalian aset milik Korporasi dari hasil tindak pidana atau aset yang digunakan untuk melakukan tindak pidana. Ketentuan pasal 8 PerMA No. 13 tahun 2016 tersebut dapat digunakan oleh oknum-oknum yang hendak melakukan suatu tindak pidana. Mereka dapat mendirikan korporasi untuk melakukan kejahatan lalu membubarkannya agar mereka tidak dapat dimintai pertanggungjawaban pidana.

Menyadari adanya celah dalam ketentuan hukum tersebut, Mahkamah Agung kemudian mengaitkan pasal 8 tersebut dengan pasal 16 PerMA No. 13 tahun 2016, yang menyatakan bahwa:

(1) Dalam hal ada kekhawatiran Korporasi membubarkan diri dengan tujuan untuk menghindari pertanggungjawaban pidana, baik yang dilakukan sesudah maupun sebelum penyidikan, Ketua Pengadilan Negeri atas permintaan penyidik atau penuntut umum melalui suatu penetapan dapat menunda segala upaya atau proses untuk membubarkan Korporasi yang sedang dalam proses hukum sampai adanya putusan berkekuatan hukum tetap.

(2) Penetapan pengadilan sebagaimana dimaksud pada ayat (1) hanya dapat diberikan sebelum permohonan penundaan kewajiban pembayaran utang atau permohonan pailit didaftarkan.

(3) Penetapan pengadilan sebagaimana dimaksud pada ayat (1) tidak dapat diajukan terhadap Korporasi yang bubar karena berakhirnya jangka waktu sebagaimana ditentukan dalam dokumen pendirian.

Pasal 16 PerMA No. 13 tahun 2016 tersebut telah mengantisipasi adanya kekhawatiran korporasi membubarkan diri untuk menghindari pertanggungjawaban pidana. Cara yang dilakukan adalah dengan meminta penetapan dari Ketua Pengadilan Negeri atas permintaan dari penyidik atau penuntut umum untuk menunda segala upaya atau proses pembubaran korporasi yang sedang dalam proses hukum sampai adanya putusan berkekuatan hukum tetap. Sehingga dari adanya kedua pasal tersebut, dapat ditarik suatu pemahaman bahwa korporasi yang sudah bubar, tidak dapat dimintakan pertanggungjawaban pidana. Namun apabila proses pembubaran tersebut masih dapat ditunda, maka penyidik atau penuntut umum dapat meminta penetapan 
dari Ketua Pengadilan Negeri untuk menunda segala upaya hukum atau proses pembubaran korporasi tersebut. Namun kedua pasal tersebut juga masih belum sempurna karena adanya ketentuan Penetapan Pengadilan sebagaimana yang dimaksud tersebut tidak dapat diajukan kepada Korporasi yang bubar karena berakhirnya jangka waktu pendirian Korporasi.

Hal lainnya yang menjadi kajian adalah adanya ketentuan dalam pasal 12 PerMa No. 13 tahun 2016, yang menyatakan bahwa:

(1) Surat dakwaan terhadap Korporasi dibuat sesuai dengan Kitab Undang-Undang Hukum Acara Pidana (KUHAP).

(2) Bentuk surat dakwaan sebagaimana dimaksud pada ayat (1) merujuk pada ketentuan pasal 143 ayat (2) Kitab Undang-Undang Hukum Acara Pidana (KUHAP) dengan penyesuaian isi surat dakwaan sebagai berikut:

a. nama Korporasi, tempat, tanggal pendirian dan/atau nomor anggaran dasar/akta pendirian/peraturan/dokumen/perjanjian serta perubahan terakhir, tempat kedudukan, kebangsaan Korporasi, jenis Korporasi, bentuk kegiatan/usaha dan identitas pengurus yang mewakili; dan

b. uraian secara cermat, jelas dan lengkap mengenai tindak pidana yang didakwakan dengan menyebutkan waktu dan tempat tindak pidana itu dilakukan.

Ketentuan dalam PerMa No. 13 tahun 2016 tersebut berkaitan dengan pasal 143 ayat (2) KUHAP, menentukan bahwa:

(2)Penuntut umum membuat surat dakwaan yang diberi tanggal dan ditandatangani serta berisi:

a. nama lengkap, tempat lahir, umur atau tanggal lahir, jenis kelamin, kebangsaan, tempat tinggal, agama dan pekerjaan tersangka;

b. uraian secara cermat, jelas dan lengkap mengenai tindak pidana yang didakwakan dengan menyebutkan waktu dan tempat tindak pidana itu dilakukan.

Ketentuan hukum tersebut merupakan aturan dalam KUHAP yang masih berpedoman pada KUHP yang tidak mengenal korporasi sebagai subyek hukum. Dengan demikian, aturan di dalam KUHAP sendiri juga tidak mengenal korporasi sebagai subyek hukum. Menjembatani hal tersebut, PerMA No. 13 tahun 2016 dalam membuat surat dakwaan untuk Korporasi tetap berpedoman pada KUHAP namun diadakan beberapa penyesuaian sebagaimana ditentukan dalam pasal 12 ayat (2) PerMA No. 13 tahun 2016.

Ketentuan yang sama juga berlaku terhadap putusan baik berupa putusan pemidanaan maupun putusan bukan pemidanaan. Pasal 24 PerMA No. 13 tahun 2016 menentukan bahwa putusan terhadap korporasi dibuat sesuai dengan KUHAP dan mencantumkan identitas yang telah disesuaikan dengan ketentuan dalam PerMA No. 13 tahun 2016. Kedua hal ini kemudian menimbulkan suatu pemikiran yang mampu menjadi landasan ketentuan tersebut dapat menjadi cikal bakal dibentuknya pembaharuan hukum acara yang mengakomodasi subyek hukum korporasi.

Setelah membahas mengenai pertanggungjawaban pidana, pembahasan selanjutnya adalah mengenai pidana yang dapat dijatuhkan terhadap korporasi. Hukum pidana mengenal jenis-jenis pidana berupa pidana pokok dan pidana tambahan. Pasal 10 KUHP menentukan bahwa pidana pokok terdiri dari pidana mati, penjara, kurungan, denda, dan tutupan. Pidana tambahan itu sendiri terdiri dari pencabutan hak-hak tertentu, perampasan barang-barang tertentu, serta pengumuman putusan hakim.

Berkaitan dengan pidana tersebut, Pasal 25 PerMA No. 13 tahun 2016 menentukan bahwa: 
Jurnal Yustika

Vol. 21 No. 2, Des 2018

Halaman I 9

Formulasi

Pertanggungjawaban Pidana

Korporasi Dengan

Adanya Peraturan

Mahkamah Agung

No. 13 Tahun 2016

Michelle Kristina

(1) Hakim menjatuhkan pidana terhadap Korporasi berupa pidana pokok dan/atau pidana tambahan.

(2) Pidana pokok yang dapat dijatuhkan terhadap Korporasi sebagaimana ayat (1) adalah pidana denda.

(3) Pidana tambahan dijatuhkan terhadap Korporasi sesuai dengan ketentuan peraturan perundang-undangan.

Menurut pendapat yang disampaikan oleh Niniek Suparni, menyatakan bahwa:

Pidana denda yang apabila dihubungkan dengan tujuan pemidanaan, lebih diutamakan dalam delik-delik terhadap harta benda. Sehingga harus dicari keserasian antara kerugian yang ditimbulkan oleh suatu tindak pidana dengan besarnya pidana denda yang harus dibayar oleh terpidana. Oleh karena itu harus dipertimbangkan dengan seksama, minimum maupun maksimum pidana denda yang diancamkan terhadap suatu tindak pidana.

Disadari pula dengan berkembangnya jenis-jenis delik baru dalam masyarakat (khususnya dalam bidang perekonomian yang diakibatkan oleh kemajuan ilmu pengetahuan dan teknologi yang sangat pesat), maka di samping ganti kerugian, pidana denda akan menempati kedudukan yang penting. Terlebih lagi apabila dihubungkan dengan tindak pidana yang dilakukan oleh korporasi (Niniek Suparni, 2007).

Berdasarkan pendapat tersebut, pidana denda semakin memegang peranan penting dalam tindak pidana yang berhubungan dengan bidang perekonomian termasuk tindak pidana yang dilakukan oleh korporasi.

Menurut Barda Nawawi Arief, menyatakan bahwa konsep tujuan pemidanaan adalah perlindungan kepada masyarakat dan perlindungan/pembinaan terhadap individu pelaku tindak pidana. Aspek lain dari perlindungan terhadap masyarakat adalah adanya perlindungan terhadap korban serta pemulihan keseimbangan nilai yang terganggu akibat adanya tindak pidana tersebut (Barda Nawawi Arief, 1996). Pendapat tersebut dikaitkan dengan adanya konsep pidana pokok dan pidana tambahan yang dapat dijatuhkan kepada korporasi menunjukkan bahwa PerMA No. 13 tahun 2016 tersebut berupaya menyerasikan kerugian yang ditimbulkan akibat tindak pidana yang dilakukan oleh korporasi dengan pidana yang dapat dijatuhkan kepada korporasi. Dengan menjatuhkan pidana pokok berupa pidana denda, maka korporasi diharapkan mampu mendapatkan efek jera.

Ketentuan hukum Pasal 30 PerMA No. 13 tahun 2016, menentukan bahwa: "Pidana tambahan atau tindakan tata tertib atau tindakan lain terhadap Korporasi dilaksanakan berdasarkan putusan Pengadilan". Dengan demikian, pidana tambahan yang dimaksudkan dalam PerMA No. 13 tahun 2016 tersebut tidak hanya sebatas pada pidana tambahan yang dimaksud dalam KUHP melainkan juga pidana tambahan lainnya yang diatur dalam peraturan perundang-undangan, contohnya seperti pidana tambahan yang diatur dalam Pasal 18 UU Tindak Pidana Korupsi. Ketentuan dalam PerMA No. 13 tahun 2016 tersebut juga sejalan sebagaimana terlihat dalam pasal 32, menentukan bahwa "Korporasi yang dikenakan pidana tambahan berupa uang pengganti, ganti rugi dan restitusi, tata cara pelaksanaannya dilakukan sesuai dengan ketentuan peraturan perundang-undangan". Lebih lanjut, Pasal 33 PerMA No. 13 tahun 2016 juga menentukan jenis pidana tambahan bagi korporasi berupa perbaikan kerusakan akibat tindak pidana yang dilakukan. Hal ini sejalan dengan maksud dari adanya tujuan pemidanaan sebagaimana telah dikemukakan oleh Barda Nawawi Arief, yaitu adanya pemulihan nilai di masyarakat yang telah tercederai dengan adanya tindak pidana tersebut. 


\section{Kesimpulan}

Berdasarkan pemaparan yang telah disampaikan, korporasi mampu memberikan kontribusi dalam memenuhi kebutuhan hidup manusia, namun disisi yang lain, perkembangan konsep mengenai korporasi ini juga diikuti dengan semakin berkembangnya kejahatan yang dapat dilakukan dengan menggunakan korporasi atau disebut pula sebagai kejahatan korporasi. Kata "korporasi" itu sendiri merupakan sebuah istilah yang biasa digunakan untuk menyebut badan hukum (rechtpersoon). Pengertian tentang "korporasi" itu sendiri merupakan hasil dari konsep pemahaman tentang subyek dalam bidang hukum yang dapat dimintakan pertanggungjawaban pidana.

Pada awalnya hukum pidana Indonesia tidak mengenal Korporasi sebagai subyek hukum pidana (asas Universitas Delinquere Non Potest) namun hal tersebut telah berkembang sesuai dengan perkembangan jaman pula yaitu ditandai dengan diakuinya badan hukum atau korporasi sebagai subyek hukum pidana dalam peraturan perundang-undangan lebih khusus. Banyaknya peraturan perundang-undangan yang sudah mengakomodir korporasi sebagai subyek hukum yang dapat dimintai pertanggungjawaban pidana belum diikuti dengan peraturan yang mengatur mengenai prosedur atau tata cara pemeriksaan korporasi sebagai pelaku tindak pidana.

Menanggapi kebutuhan hukum yang sudah sangat mendesak serta adanya perlakuan yang berbeda mengenai tata cara penanganan terhadap korporasi maka Mahkamah Agung mengeluarkan PerMA No. 13 tahun 2016 yang berbicara mengenai hukum formil atau hukum acaranya. Tidaklah mudah untuk dapat memidanakan korporasi yang melakukan tindak pidana sebagaimana ditentukan oleh undang-undang. Salah satu maksud dan tujuan dibentuknya PerMA No. 13 tahun 2016 tersebut adalah guna mengisi kekosongan hukum acara pidana yang mengatur mengenai tata cara penanganan korporasi yang melakukan perkara pidana.

Berdasarkan analisis yang telah diberikan dalam membahas pasal-pasal yang ada dalam PerMA No. 13 tahun 2016 dengan undang-undang lainnya seperti KUHAP dan UU Tindak Pidana Korupsi, dapat diambil kesimpulan bahwa PerMA No. 13 tahun 2016 tersebut berusaha menjembatani adanya kekosongan hukum yang terjadi karena KUHAP sampai saat ini belum mengakomodasi subyek hukum korporasi. Dengan demikian, peraturan perundang-undangan di Indonesia, khususnya KUHAP, UU Tindak Pidana Korupsi, dan PerMA No. 13 tahun 2016 telah mengatur secara tepat tata cara penanganan terhadap korporasi yang melakukan tindak pidana.

\section{Daftar Referensi}

Ali, Mahrus. (2008). Kejahatan Korporasi, Yogyakarta: Arti Bumi Intaran. (2013). Asas-Asas Hukum Pidana Korporasi, Jakarta: Raja Grafindo Persada.

Arief, Barda Nawawi. (1996), Bunga Rampai Kebijakan Hukum Pidana, Cet. I, Jakarta: Citra Aditya Bakti.

Hartanti, Evi. (2005). Tindak Pidana Korupsi, Jakarta: Sinar Grafika.

Setiyono. (2005). Kejahatan Korporasi, Malang: Bayumedia Publishing.

Sjahdeini, Sutan Remy. (2007). Pertanggungjawaban Pidana Korporasi, Jakarta: Grafiti Pers.
Jurnal Yustika

Vol. 21 No. 2, Des 2018

Halaman | 10

Formulasi

Pertanggung-

jawaban Pidana

Korporasi Dengan

Adanya Peraturan

Mahkamah Agung

No. 13 Tahun 2016

Michelle Kristina 
Suparni, Niniek. (2007). Eksistensi Pidana Denda dalam Sistem Pidana dan Pemidanaan, Jakarta: Sinar Grafika.

Jurnal Yustika

Vol. 21 No. 2, Des 2018

Halaman | 11

Formulasi

Pertanggung-

jawaban Pidana

Korporasi Dengan

Adanya Peraturan

Mahkamah Agung

No. 13 Tahun 2016

Michelle Kristina
Yunara, Edi. (2005). Korupsi dan Pertanggungjawaban Pidana Korporasi: Berikut Studi Kasus, Bandung: Citra Aditya Bakti. 